\title{
Thematic vs Chronological History Teaching Debate: A Social Media Research
}

\author{
Ibrahim Turan $^{1}$ \\ ${ }^{1}$ HAY School of Education, Istanbul University-Cerrahpasa, Istanbul, Turkey \\ Correspondence: Ibrahim Turan, HAY School of Education, Istanbul University-Cerrahpasa, Yigitturk Caddesi \\ No: 5/7 Buyukcekmece Yerleskesi, Buyukcekmece, Istanbul, Turkey. E-mail: ibrahim.turan@istanbul.edu.tr
}

Received: November 22, 2019

Accepted: December 29, 2019 Online Published: January 9, 2020

doi:10.5539/jel.v9n1p205

URL: https://doi.org/10.5539/jel.v9n1p205

\begin{abstract}
At the beginning of the 19th century, history education has found its place as an independent course in formal education institutions, since then it has undergone many reforms and revisions but none of these reforms has solved its chronic problems. In discussions on how to solve the problems of teaching history, one of the most important issues is whether history should be taught chronologically or thematically. The purpose of this research is to review the discussions on this topic in Internet blogs to examine teachers' views on the advantages and disadvantages of these two approaches. The social media research method was applied in this research. Required data obtained through teachers' blogs on thematic and chronological history teaching and teachers' comments on the subject in these blogs. The thematic content analysis carried out with the NVivo program, which helped in-vivo codes emerged from teachers' blogs and comments. Most of the 71 teachers whose remarks are referenced in the research have expressed a positive view on thematic history teaching, although it is more difficult to understand and apply. Some teachers proposed a mixed approach in which the thematic and chronological approach is combined in different order and proportions based on students' grades.
\end{abstract}

Keywords: chronological history, thematic history, teachers' view, history teaching, social media research

\section{Introduction}

Even though two centuries have passed since history began to be taught in high schools as a separate independent course (Documents upon Napoleon, t.y.), history teaching has not survived its chronic problems. During this period, its scope, focus, teaching programs, textbooks, teaching materials have changed, and even teaching history combined with other subjects has been re-tried. All these revision or reform attempts have unfortunately failed to provide the desired progress in the learning and retention of historical knowledge, which basically includes names, dates, events, and chronological order. Academic studies conducted in the last hundred years show that the rate of recalling the historical knowledge by the students is much lower than expected (Safran \& Şimşek, 2006; Pala \& Şimşek, 2016; Wineburg, 1995; De Voto, 1943; Eikenberry, 1923; Bell \& McCollum, 1917). In addition to recalling names and dates, it is seen that the students are not at the desired level in sorting the events in chronological order (Çelikkaya \& Kürümlüoğlu, 2019; Safran \& Şimşek, 2006). Therefore, despite all the changes that have taken place in the last two centuries, we can say that one thing never changed in history teaching is the low retention rates of historical knowledge.

One of the most debated issues when searching for solutions to the chronic problems of history teaching is whether history should be taught chronologically or thematically. The first point that needs to be clarified before entering deeply into this discussion is that these two approaches should not be considered as an alternative to each other (Şimşek, 2017, p. 142). When its first example was put forward by Morrison in 1926 under the name of "Unit Plan" the aim of thematic approach was not to completely abandon the chronological approach (Smith, 1930), but rather to solve chronological approach's focusing problem with central themes, thus making history teaching more meaningful, logical, and psychologically appealing to students (Smith, 1930; Fabiano, 1962). This approach, which was supported by Bruner's meaning-centered cognitive theory in the following years, has been applied in many countries and has been subject to many studies. The School History Project (SHP), which was initiated in the 1970s in England, has led to the implementati on of the thematic history teaching in many schools (Smart \& Harnett, 2009, p. 113). Although the thematic approach has been around for almost a hundred years, to a great extent, history continues to be taught within the framework of the chronological approach. The 
chronological approach is still the dominant teaching model, even in the United States, where this approach first emerged, and in the UK (Cannadine, Keating, \& Sheldon, 2011), where the focus of history teaching has been changed to innovative teaching methodology, and historical skills by the new history initiative (Waldman, 2009; Phillips, 1999).

The widespread use of chronological history teaching stems from two claims; first, history cannot be comprehended without chronology, and the second, chronological approach is a more effective method in teaching historical chronology because it is easy to understand and appropriate for all ages. The first claim has been emphasized by many historians and even some defined chronology as the backbone of history (Şimşek \& Bal, 2010). The privileged status of chronology and chronological skills is confirmed in the current Turkish high school history curriculum as follows:

Chronological thinking is the basis of the science of history. Chronology is when and in what order events took place. Without chronology skills, it is impossible for students to examine the relationships between events or explain cause-effect relationships in history. Chronology serves as a mental structure that regulates historical thinking. The prerequisite for developing this skill is teaching concepts of time (day, month, year, period, age, etc.), calendar types and related basic concepts (BC, MS, century, etc.) comparatively (MEB, 2018a, p. 13).

In the current Social Studies curriculum for primary and middle schools, chronology has been handled under the perception of time and chronology skill, and it has been set as main skill in many learning domains (MEB, 2018b). However, in the 8th-grade T.R. Revolution and Kemalism course curriculum, which is another middle school history course, chronology knowledge or skill was not mentioned at all (MEB, 2018c). Current curriculums also promote moving away from traditional chronology teaching. For example, the high school history curriculum in Turkey emphasizes the development of chronological thinking skills and suggests teachers over and over avoiding memorization (MEB, 2018a).

The claim that the chronological approach is the most effective method to improve the perception of chronological order or historical time, has been criticized by some researchers. These researchers argue that children's perception of chronological order or historical time does not develop by sequential information but by comparing people, events, and periods with specific reference points (Stow \& Haydn, 2000; Barton, 2009, p. 267). Again, although many researchers have suggested that the chronological approach is suitable for all ages, it cannot be said that a full consensus has been reached on this claim either. Some of the research on chronology knowledge or skills support Piaget's cognitive developmental stages and suggest teaching of chronological knowledge and skills in the formal operations stage $($ age +11$)$. Some other researchers claim even young children can grasp chronology knowledge and skills with appropriate methods and approaches (Şimşek, 2006).

According to academicians who support the thematic approach, chronological approach, which they see as the main actor of traditional history teaching, does not meet today's needs and lags behind the current understanding of education. For this reason, some researchers advocate the thematic approach and blame the chronological approach for the current state of history teaching. Tanaka, one of these researchers, describes the current problems of history teaching and the effect of the chronological approach on this situation in his book titled "History Without Chronology" as follow:

This centrality of historical thinking contrasts with the current worries in the discipline of history about a decline in interest and attention (and significance?) as well as a rise of a presentist mindset. Historians have generally blamed external factors, especially the denigration of humanistic understanding in favor of science and technology. While there is a good reason for such a view, historians have ignored internal issues; we have so naturalized our processes that we have overlooked how history itself is a part of the problem. I agree with Ermarth $(1992,2011)$, who suggests that the history that developed over the twentieth century no longer matches changes to our societies conceptually, practically, or scientifically... A naturalized chronological time is the foundation of this disconnect (2019, pp. 52-53).

In the same work, Tanaka refers to Voltaire and Hegel, founders of the philosophy of history, and argues that these two pioneers pave the way for the separation of the metric chronological system from the knowledge of the past. According to Tanaka, when this is done, history will not be separated from chronology but a more understandable and natural chronological time will continue to be included in the knowledge of the past (2019, $\mathrm{p}$. 93). Tanaka foresees "a richer, complex interaction between things before" if the current "chronological structure is decentered" $(2019$, p. 53).

The view that the thematic approach is more appropriate to learning theories than the chronological approach is basically based on the new findings on learning and memory. There are two ways in which the human brain can 
remember new information: memorization and meaning-making (linking with other information). The first of these, the information obtained through memorization is less persistent and the acquisition of this information is not accepted by many contemporary educational scientists as learning. According to contemporary learning theories, the human brain creates a complex network of connections (schema) between newly acquired knowledge and related information. In this process, information is connected to the old and relevant information and increases exponentially. The thematic approach allows students to see these connections by addressing many similar events and phenomena around a central theme (Hopkins, Peters, \& Schubeck, 1995, p. 633). Teaching with themes chosen from among the common concepts and events that students encounter in daily life could increase the probability of remembering new information (Proust phenomenon) as well as provide meaningful learning that focuses on the main ideas, in other words, the big picture.

Besides the association, the effect of narrative on memory should be discussed as well. In a thematic approach, events that occurred in different times and regions are taught interconnected. Contrary to what the chronological approach claims, the sequential arrangement of events is not a system that makes it easier to remember. Because often the only thing these events share in common is that they occur one after the other. Although the story told in the thematic approach is temporally and spatially disconnected, it still develops around a certain theme. In the thematic approach, a more familiar narrative is used which is arranged in the order of introduction, body, and conclusion with a certain beginning and end. This approach increases the likelihood of recalling historical knowledge with the exception of the date and maybe the sequence of events.

Unlike the chronological approach which focuses on facts, events, names, dates, and order of events in specific time periods, the thematic approach focuses on the main ideas. This approach examines a series of events under a particular concept and helps students develop questioning skills and a better understanding of cause-and-effect relationships. The identified theme or concept serves as a lens to identify, analyze, redefine, test and reassemble the relevant events to develop theories that will make it easier to understand new events (Zevin, 2000, p. 244).

Among the most criticized features of the thematic approach are the weakness in teaching chronology and the cause-effect relationship, and the idea that it teaches less history by making a selection within grand historical knowledge. According to the proponents of the thematic approach, nowadays this selection has become a necessity. History teachers cannot continue their efforts to teach all events from the big bang to the present day. Contrary to popular belief, however, the thematic approach does not teach less history by discarding certain subjects. The thematic approach is to teach children more on less topics to ensure that children have an in-depth knowledge of history (White, 1994, p. 58). Due to the limitations (some define it as a gift) of the brain (Borges, 1999), it is only possible to see the big picture by sacrificing less important events and facts for the sake of more important ones.

Examining the literature on the thematic and chronological history teaching reveals that there are many studies advocate both approaches and explain how to plan and implement appropriate teaching according to these approaches. In recent years, it is possible to say that the studies on the thematic approach have increased rapidly and the interest in the thematic approach has increased among both academics and teachers. According to a survey conducted by EUROCLIO among history teachers in 2003, thematic curricula in chronological order are becoming more common in European countries (Koren \& Najbar-Agicic, 2007). For example; resent history programs in the UK have made it necessary to teach local, national, European and world history through specific thematic units (Harnett, 2019, p. 150). This is not an indication that one of these two methods is better than the other (as discussed earlier these two methods are not alternatives to each other), but a change in the goals of history teaching.

It will be useful to examine the attitudes and views of the teachers who will have the most impact on the outcome of such a change process which supposed to alter the scope, focus, and method of history teaching. Theoretical or empirical studies on the subject may explain how the thematic approach can radically change history teaching when appropriate conditions are met. On the other hand, only teachers can explain whether these so-called appropriate conditions can be achieved in practice. They can reveal the problems experienced during the implementation of the thematic method, and determine whether the possible outcomes are worth the effort by doing the labor-benefit comparison.

Unfortunately, there is no study in the literature directly examining teachers' views on thematic and chronological approaches. This issue has only been partially addressed in some studies. Harris and Burn (2016), asked a similar question to British history teachers and $71 \%$ of them rejected the claim that the chronological history teaching strengthens students' chronological perceptions of the past. Altınyelken (2010) found that after a switch from chronologic curriculum to thematic, teachers in Uganda experienced great difficulties in the 
implementation of the new program due to structural problems, lack of materials and teacher training. In Turan's (2018) study, 11 of the 22 history teachers who participated in the study supported chronological approach in the curriculum, 10 supported partly chronological partly thematic approach, and only one teacher supported thematic history curriculum.

\section{Method}

\subsection{Aim of the Study}

The aim of this research is to reveal the teachers' views on chronological and thematic history teaching by examining the discussions on the topic in different blogs, through social media research.

\subsection{Research Questions}

1) According to teachers, which approach is more effective in teaching history/social studies?

2) According to teachers, what are the advantages and disadvantages of both approaches?

\subsection{Design of the Study}

The design of the study is Social Media Research. In its simplest definition, social media research refers to tools and techniques for extracting and analyzing data from social media channels and the Internet. Social media can be defined as platforms that allow users to share and communicate on the internet. Social media platforms include blogs (WordPress. Blogger, Blogspot, etc.), microblogs (Twitter, Tumblr, etc.), Social Networks (Facebook, MySpace, etc.), Content Communities (YouTube, Daily Motion, Pinterest, Instagram, Flickr, Vine, etc.), Joint Projects (Wikipedia), Virtual Gave Worlds (World of Warcraft), and Virtual Social Worlds (Second Life, Farmville) (Kaplan \& Haenlein, 2010).

The reason why blogs were chosen among the other social media tools as a data source of this study was the fact that compared to other social media tools, blogs allow sharing content in various formats (pictures, videos, audio files, Word documents, PDFs, etc.) and without any character limitation. Also, blogs are environments that allow link sharing and mutual and confidential communication with blog followers. Nowadays, many teachers are able to share their experiences on blogs as an online diary and receive feedback from colleagues and experts about the methods, tools, or problems they encounter.

Advantages of blogs as a data source include: full protection of participant privacy, the minimum risk for the participant, honest and sincere answers, affordability, access to a wide range of participants from different geographies, and the ability to select purposeful samples (Hewson, 2014; Jainson \& Payne, 2007). All these features have made blogs a fast and reliable source of information for academic research which seeks solutions to current problems (Powell, Jacob, \& Chapman, 2012). Therefore, today, many social scientists use blogs as a data source in their research (Wakeford \& Cohen, 2008). On the other hand, the reliability of this method and the generalizability of the research findings are questioned.

\subsection{Data Collection and Analysis Process}

A quantitative thematic content analysis was used in this research. According to Bardin (2009, cited in Oliveria et al., 2013), a thematic content analysis consists of three stages: pre-analysis, exploration, and treatment. On the pre-analysis stage, first, a very general search was made both in the Turkish and English languages using the keywords "thematic history, chronological history" on the Internet. Examination of the Internet search results was used to determine and select relative blogs consistend with the objectives of the research.

The pre-analysis of the Internet search results showed that there is no web-blog created by Turkish history or social studies teachers on the subject of thematic or chronologic history teaching. However, 14 blogs were identified in English language which were created by teachers on eight blog sites: Blogspot.com, Wordpsess.com, Reddit.com, Teachers.net, The Civic Educator, Teachinghistory.org, A to Z Teacher Stuff, and MiddleWeb Blog. Along with the blog contents, the reader comments were also pre-analyzed to identify comments written only by teachers. Of the over a hundred readers' comments, only those assured to be written by teachers are considered for evaluation. These blog contents, discussions and comments were transferred to the NVivo program and subjected to thematic content analysis in which the codes were not pre-determined but they emerged from teachers' blogs and comments as in-vivo codes.

\section{Results}

The majority of the 14 blogs examined within the scope of the research were written by teachers who applied the thematic approach in their classrooms and wanted to share their experiences with other teachers. A small portion of these blogs can be classified as (neutral) that try to find out which of these two approaches would be more 
appropriate in history teaching by asking experienced teachers. However, no blog promoting or explaining the chronological approach was encountered.

The findings in this section were obtained from the analysis of blog contents and comments of 71 history and social studies teachers in 14 blogs. Only small portions of the teachers in the study group clearly stated the country or city in which they live in their blogs or comments and those who did so live in the USA, Canada, and Australia.

Table 1. Teachers' preferences by type of approach

\begin{tabular}{ll}
\cline { 2 - 2 } Approach & f \\
\cline { 2 - 2 } Thematic & 40 \\
Practitioner & 12 \\
Thinking to Practice & 28 \\
Chronological* & 15 \\
Mix (Chrological + Thematic) & 12 \\
Other + Undecided & 4 \\
\hline Total & $\mathbf{7 1}$ \\
\hline
\end{tabular}

Note. * Including back-chronology.

Within the scope of the research, firstly, teachers' views toward thematic and chronological approaches were examined. Thematic content analyses show that more than half of the 71 teachers in the study group are in favor of the thematic approach. However, these numbers do not reflect the actual implementation rate of the thematic approach. In-depth analysis shows that the number of teachers applying the thematic approach already in their classrooms is lower than the chronological approach. Although the majority of the teachers prefer the thematic approach, the low rate of implementation of this approach seems to be due to two reasons. The first in some schools teachers are not granted autonomy in curriculum development, and the second teachers who wish to adopt a thematic approach remain in the minority in their schools. A teacher nicknamed StrangerintheAlps stated this situation as: "I have always wanted to teach history through the thematic method. Unfortunately, in the school where I work, all teachers are asked to strictly follow the same program."

When the application rates are examined, it is seen that the number of teachers practicing the chronological approach in their teaching is slightly more than the teachers practicing the thematic approach. In fact, the actual rate of use indicated for the chronological approach is actually greater than what is shown in Table 1 . The difference between preference and application rates is caused by both external internal reasons for teachers. The external reason as explained before is that teachers' obligation to use a chronological approach other than their own preferences. The internal reason is the teachers' unfamiliarity with or in other words the low level of knowledge on the implementation of this approach. Those teachers with a positive view of the thematic approach but cannot apply it due to external or internal reasons are coded under the "Thinking to Practice" group in Table 1. It also should be noted that the majority of the blogs examined within the scope of this research were created by teachers who advocate thematic approach and the majority of those who visited these blogs were also the ones who are interested in this approach and therefore seeking information about it. Perhaps this is why the largest group is turned out to be the teachers who are "Thinking to Practice" thematic approach in the near future. Another interesting finding is the majority of those who desire to try the thematic approach are newcomers to teaching. Some experienced teachers are also thinking of moving to a thematic approach because of the problems they face in the chronological approach. These teachers express their reasons as follows:

"Hey, found your blog randomly through a google search about teaching history thematically and love what you've written about. This will be my first year teaching and I think teaching history thematically makes way more sense and o ers more possibilities for really engaging students..." (Caitlin)

"...I have been looking for a different way to teach my world history course other than chronological, and this speaks to me..." (Cody)

“...I too struggled with this decision. Typically, I went with chronological order, but I think thematic would have been more beneficial due to the importance of social factors in cognition..." (Dave)

Within the scope of the second research question, the advantages and disadvantages of both approaches in practice were tried to be determined by examining the history teachers' justifications when specifying their teaching approach preferences. 
Teachers have expressed the same number of disadvantages $(f=13)$ for both approaches but stated that the thematic approach provides more advantages $(f=14)$ in comparison to the chronological approach $(f=4)$. The advantages and disadvantages expressed by teachers for both approaches can be seen in Tables 2 and 3 .

\subsection{Advantages and Disadvantages of Thematic Approach According to Teachers}

Table 2. Advantages and disadvantages of thematic approach expressed by teachers

\begin{tabular}{ll}
\hline Advantages & Disadvantages \\
\hline 1. More appropriate for the use of student-centered methods & 1. Difficult to learn how to implement \\
(project-based learning, cooperative learning, group work, etc.) & 2. Not suitable for all ages \\
2. Good for teaching with multiple perspectives (examining history & 3. Not suitable for teaching chronology \\
with multiple perspectives) & 4. Not successful in teaching cause-effect relationship \\
3. Fun/Not Boring & 5. Themes are subjective (not natural, coercive) \\
4. Provides meaningful learning & 6. Not a real solution, but a superficial solution to content density \\
5. Allows students to be more creative & 7. Difficult to understand by students because it is a nonlinear \\
6. Supports a deeper understanding of the events & teaching \\
7. Provides an opportunity to see the big picture & 8. Contains repetition \\
8. More effective in teaching historical thinking skills & 9. Disconnection: Difficult to establish a connection between \\
9. Makes recalling easy & themes \\
10. Enables catching up current issues & 10. Themes do not make sense to students \\
11. Provides an opportunity for historical learning beyond the & 11. Requires uninterrupted attendance of students \\
textbook & 12. Serves for hidden curriculum program (propaganda) \\
12. Focus on skill rather than knowledge & 13. Difficulty to determine the content, (decide what to \\
13. More suitable for citizenship education & include/exclude) \\
14. Saves time & \\
\hline
\end{tabular}

\subsubsection{Advantages of the Thematic Approach According to Teachers}

Teachers whose opinions were consulted within the scope of the research specified thirteen advantages of the thematic approach. According to teachers, the thematic approach allows students to see the interconnections between events which helps them to develop a more holistic knowledge of history, and this was the most frequently mentioned advantage of the thematic approach. It is also often emphasized that thematic teaching makes students enjoy history by going beyond traditional history teaching. A teacher with the nickname Brian stated: “... The students are enjoying it. Many have said history is their favorite class this year and some said it's the class they are looking most forward to every week. That's strange? Isn't it? Isn't it usually the class people generally say is the most boring? One of the issues frequently raised is that the thematic approach does not neglect current issues. According to the teacher named Dlaufenberg; "I believe that a thematic approach moves away from the march of chronology which invites a more fluid inclusion of current events in the study of history. Those that run out of time are trying to teach a timeline..."

Another finding that emerges in this research is that some teachers think the thematic approach changes the protagonists and the audience of history. Referring to the use of multiple perspectives and the use of social history rather than political and military history in the thematic approach they claim ordinary people can become the protagonists of history so that history education can appeal to students from the different socio-cultural background.

"When you sell a brand or a product to a customer, the goal is not to make the customer a part of your brand or product. It is the other way around. You make your brand/product a part of your customer's story. There is no better storyteller than the main character themselves. Let's put it this way. Most people like to talk about themselves. People are more passionate when it comes to talking about themselves. When you tell someone else's story, you're most likely not as enthusiastic about it than when telling your own experience." (Brian)

\subsubsection{Disadvantages of Thematic Aapproach According to Teachers}

According to the teachers whose opinions were examined within the scope of the research, the biggest disadvantage of the thematic approach that it is a new, little-known and therefore seems more difficult method. Since history books and traditional history teaching are chronological, many people, as well as teachers, have quite limited knowledge of the thematic approach. Therefore, it is not easy for even teachers who are facing the issues of the chronological approach to switch to thematic in a snap. Teachers who wish to practice the thematic 
approach are having problems in determining the content, themes, the order of themes, appropriate teaching methods and materials to use with this approach. As they see the success stories of thematic teaching, they are interested in this approach, but they are also aware that they need support. For this reason, many teachers are visiting these blogs and requesting programs and materials from their experienced colleagues.

Many teachers acknowledge that the thematic approach might not be particularly appropriate for young children. Those who have this view suggest that the thematic approach should be applied to high school students. However, for some teachers, this approach can be practiced in the 8th grade American History course with a few minor measures to help students to overcome aforesaid difficulties. However, according to one teacher, it is difficult to apply this approach at 10th or 11th grades:

"I go chrono but with some flexibility, so for example, I'm not covering the Monroe Doctrine until we get to imperialism at the turn of the century. I tried a more (but not purely) thematic approach last year and students complained and got confused. I think for students who don't already have a sense of the sequence of things, it can be a challenge. I teach generally unprepared 10th graders in an urban setting and they have no idea, by and large, what happened before what, so I think that's healthy, especially in the 20th century, because things are so closely linked from WWI to the depression to WWII to the cold war and the counterculture/civil rights movement to Nixon and the war on drugs and Reagan, etc." (WillPE)

Another common frequently stated disadvantage of the thematic approach was its failure to teach chronological knowledge and skills. It was stated that students have difficulty in keeping important dates in mind, and putting events in their order because the thematic approach does not focus sufficiently on the order of dates and events, and also it follows a non-linear, forward-backward (zig-zag) path.

"My main worry about thematic teaching was that students may get confused about when events occurred. Sure, a date can be attributed to a certain event when teaching, but students may have di culty keeping track of dates if they're not emphasized..." (Claire)

Some teachers who oppose this claim argue that with the help of some simple and not time-consuming activities such as timeline, the thematic approach can teach chronology. According to teachers, there are even student workbooks created only for this purpose. Some teachers have indicated that by using these books, besides chronology, students will be able to make connections or comparisons between events on a global scale.

Some teachers who oppose the thematic approach have argued that this approach is not a real or useful but rather a superficial solution which was introduced just to solve the intensive content problem:

“... I feel like the thematic form only came about because states required teachers to cover an insane amount of material in short spans and rather than taking the time to plan out how ideas grow over time... This leaves students with absolutely no context for topics. For instance, a commonly taught theme is Genocide and Human Rights... Yet mostly this turns into killing is bad and we shouldn't allow it, here's the Holocaust... And again, it's because you have to know how all those ideas grow in order to teach it chronologically well and that takes time. Thus "Themes!" become this great idea." (Derpy Spelling)

Another important criticism of the thematic approach is that the identified themes are subjective or coercive, in other words, they are not natural:

"... I also have a tendency to feel that "themes" are somewhat dubious. The people who experienced the events of the past had no idea or way of having an idea that they were living a "theme". They were simply reacting to the problems they were experiencing at the time." (Lynde)

"An issue with the thematic approach is that it requires a further argument about what constitutes similarity between two or more events. The concept of linear time and of cause-effect is widely-held and therefore requires little argument..." (rozumiesz) 


\subsection{Advantages and Disadvantages of Chronological Approach According to Teachers}

Table 3. Advantages and disadvantages of chronological approach expressed by teachers

\begin{tabular}{ll}
\hline Advantages & Disadvantages \\
\hline 1. Easy to understand & 1. Requires memorization \\
2. Successful in teaching chronology & 2. Cannot catch up current issues \\
3. The familiar method & 3. Tries to teach everything \\
4. Successful in teaching cause-effect relationship & 4. Teaches nothing while trying to teach everything \\
& 5. Tries to teach information that cannot be measured \\
6. Does not provide meaningful learning \\
7. Provides only superficial knowledge \\
8. Fails in knowledge retention \\
9. Students cannot see the big picture \\
10. Targets historical knowledge, not skills \\
11. Its protagonists and audience varies from thematic history \\
12. Is boring \\
13. Fails to make connections between past and present
\end{tabular}

\subsubsection{Advantages of the Chronological Approach According to Teachers}

History teachers stated that the chronological approach was effective in teaching chronology as well as an easy-to-understand method for both teachers and students. This intelligibility stems from the teaching of subjects according to a timeline, starting from 0 to the present. Another advantage of the chronological approach is that it has been practiced for a very long time so that almost everyone is familiar with it. Most of the textbooks and academic history books are designed chronologically, and this increases familiarity with the chronological approach. A teacher expressed this familiarity as follows:

“...being a person who doesn't really know my history that well, I have had to rely on the texts and learn everything myself before teaching it. So, I've taught it chronologically because that is how I tried to learn it." (Canadian Teacher)

Another advantage of the chronological approach, which is frequently mentioned by teachers, its effectiveness of teaching the cause and effect relationship. This is reflected in teacher statements as follows:

"I think taking the chronology completely away confuses students and makes it harder for them to follow cause and effect." (HeloisePemmefume)

"As much as I love the ideas that have emerged from the past two years of teaching 8th-grade history thematically, I still can't say definitively whether it's a better approach. We are able to span more eras and focus on high-interest topics, but we miss the rat-a-tat excitement of chronological history. As the year ends, I do know that the 8th graders in my class need more help realizing the importance of cause and effect." (Sarah)

\subsubsection{Disadvantages of Chronological Approach According to Teachers}

Teachers who give a negative opinion about the chronological approach defined it as a knowledge-oriented and boring approach that requires memorization, does not teach anything while trying to teach history as a whole. If it teaches anything it could only do so superficially, without examining the events in depth. Teachers supported these claims with the following statements:

“...This turns the entire subject into a matter of memorizing names, dates, and facts of dead people... There is an endless amount of facts out there. Is it possible to teach everything? ... Another problem with this traditional structure is that there is an overwhelming amount of pressure to teach as much content as possible. As a result, we can easily forget to make connections between the past and the present." (Brian)

“...I feel as though the chronologic method only scratches the surface of understanding history. Students may learn what happens, when it happens, why it happens, and who is involved, but they may not develop a deeper understanding for the history they are learning..." (Claire)

"I teach 8th grade U.S. History (up to 1877). Last year I taught it chronologically and stressed constant themes throughout such as movement of people, etc... but it seemed that students didn't comprehend the big picture like I wanted or they needed. I am considering moving to thematically organized rather than chronologically based..." (kyblue07) 


\subsection{Mixed Approach}

Teachers practicing both thematic and chronological approaches realized that in practice both approaches have weaknesses in some respects. Therefore, teachers proposed to use the synthesis of two approaches which would compensate for their deficiencies. For example, a blogger history teacher Mark Lukach uses thematic approach but to "create a certain degree of chronological literacy" for his students he spends first two weeks reading David Christian's book "This Fleeting World", also for the rest of the year they "adhere to basic chronology" within each thematic unit. Other examples of mixed approach are explained in teacher statements as follows:

"Having done both, I've finally settled on a combination. I think taking the chronology completely away confuses students and makes it harder for them to follow cause and effect. So basically, I keep with the chronology, but instead of covering everything, each week I pick a major theme to cover, while still keeping with chronology." (HeloisePemmefume)

"We do the content first half of the year (Post Revolution to Civil War) and thematic the second half. I personally prefer the thematic approach because I think you can have more direction and purpose but I see the value in both. The first half of the year provides more context and tell the story more, whereas the 2nd half is more about seeing the common threads." (th3 Dotard)

As can be understood from the teacher statements, the mixed approach is applied in different ways:

- Using a chronological approach while identifying a main theme for each week, unit, period, or century;

- Using a chronological approach while doing group work and project assignments on thematic issues,

- Using a thematic approach while arranging the themes in chronological order;

- Using a thematic approach while carrying out additional activities such as a timeline to teach chronology;

- Using both approaches, in turn, for example, the first few weeks or first period chronologically then thematic;

- Changing approach based on topic, for example, using a chronological approach on political and military history, and thematic on social, cultural and civilization history;

- Using a chronological approach in the first years of each education level and thematic approach in the following years (e.g., Turkish high school history curricula).

\section{Conclusions}

This study was aimed to reveal teachers' views on chronological and thematic history teaching by using social media research. Based on the discussions and comments on related blogs it can be concluded that the majority of history teachers think that history should be taught by the thematic approach. Although the number of teachers practicing the thematic approach is lower than chronological, those who wish or planning to use a thematic approach $(\mathrm{n}=28)$ is actually higher than all other groups. This finding supports the claim that the interest in the thematic approach has increased in recent years among teachers (Koren \& Najbar-Agicic, 2007; Harnett, 2019, p. 150). This increasing interest in thematic approach stems from intensive content, increasing focus on skill development, lower students' interest in history, and new findings in educational psychology as well as learning theories.

Despite increasing interest, the actual application rate of the chronological approach is still higher than the thematic approach, and this finding is also inconsistent with the previous studies (Cannadine, Keating, \& Sheldon, 2011). This study, based on teacher views, reveals that external reasons are more effective than teacher attitudes on low use of the thematic approach. External reasons include the limited authority of teachers in curriculum development and schools' regulations that requires all teachers to apply the same curriculum.

Teachers identified a great number of advantages and disadvantages for both approaches. In fact, the teachers mentioned almost all the advantages and disadvantages discussed in the related literature. This reveals that teachers' theoretical and practical knowledge of the subject is quite high. However, Turkish history teachers participated in Turan's (2018) study were only able to list a few advantage and disadvantage for each approach. The difference between these studies can be explained by teachers' direct experience of these approaches. Many of the teachers participating in this research have the chance to experience both approaches in different schools they teach.

The thematic approach has been widely criticized for being weak in teaching chronological knowledge and skills and as well as cause and effect. However, in an experimental study, Thacker (2007, p. 81) claims the opposite 
that the theme-based curriculum improves students' academic achievement by $17 \%$ on College Board (CLEP) U.S. History I Practice Test compared with chronologically ordered textbook-based teaching. Further empirical research is needed to establish the validity of these opposing claims.

Another claim comes from teachers practicing the thematic approach in their teaching that its weakness in teaching chronology could be overcomed with additional activities such as a timeline. This claim of the teachers coincides with the studies on using timelines in history and social studies teaching (Altun \& Kaymakc1, 2016; Şimşek, 2007). The current high school history curriculum in Turkey suggests the same activity to the teachers, in which a long chronology of important events is given in almost every unit even for the upper high school grades where the thematic approach is applied (MEB, 2018a).

This shows that both teachers and curriculum developers and experts in the field agree that the deficiencies of both approaches can be overcomed or reduced by using these two approaches together. Stradling (1997) argues that a balance must be established between the thematic and the chronological approach:

The debate on this issue sometimes seems to be based on the assumption that the two approaches are incompatible with each other. In practice, it seems to me that it is wholly possible to combine the two approaches quite effectively... What is important is that when looking at these themes and processes they are still set into the context of a broadly chronological framework not just so that they grasp the broad sequence of events but also because they can then see, for example, how apparently distinct political, social, economic, cultural and intellectual developments were actually influencing each other and may have been interdependent (1997, p. 17).

Stradling suggested teaching history in a partly chronological and partly thematic historical framework (1997, p. 18) but he also argues that the thematic approach might be more effective especially when the aim is to enable students to understand the present, or teaching historical thinking, continuity and change, and also historical research skills (2003, p. 47). We see that the mixed approach has been adopted by the Turkish Ministry of National Education in recent years so the current high school history curriculum is organized with an approach that brings together chronological and thematic approaches (MEB, 2018a, p. 11).

The success of new approach (whether mixed or pure thematic) depends on the elimination of structural problems and deficiencies, and the training of teachers. Altınyelken (2010) found that in Uganda where a thematic approach was adopted with a sudden decision, the reform initiative could not achieve the desired success due to structural problems and teacher training issues were not adequately addressed. In this study, we see that many teachers who are considering to adopt a thematic approach accept their own lack of training. Another challenge in this area is to determine the content, in other words, to identify issues to be rejected or included. In countries where teachers' academic autonomy is recognized; this decision is left to teachers in whole or in part (framework program). However, this creates a gap between schools in terms of historical knowledge and makes it difficult to carry out national tests, including the ones aiming to measure the status and quality of education. Although it seems more practical that the content is determined by field experts, unfortunately, it will not be possible to reach a consensus as long as academics see their work as more important than others.

\section{References}

Altinyelken, H. K. (2010). Curriculum change in Uganda: Teacher perspectives on the new thematic curriculum. International Journal of Educational Development, 30(2). 151-161. https://doi.org/10.1016/j.ijedudev.2009.03.004

Barton, K., \& Levstik, L. (2004). Teaching history for the common good. Mahwah, NJ: Lawrence Erlbaum Associates. https://doi.org/10.4324/9781410610508

Bell, J. C., \& McCollum, D. F. (1917). A study of the attainments of pupils in United States History. Journal of Educational Psychology, 8, 257-258. https://doi.org/10.1037/h0074477

Borges, J. (1999). Collected fictions (Çev. A. Hurley). New York, NY: Grove Press.

Cannadine, D., Keating, J., \& Sheldon, N. (2011). The Right Kind of History. Basingstoke: Palgrave MacMillan.

Çelikkaya, T., \& Kürümlüoğlu, M. (2019). Ortaokul öğrencilerinin kronoloji becerilerinin saptanmasına yönelik bir çalışma. Turkish History Education Journal, 8(1), 150-173.

De Voto, B. A. (1943). The easy chair. Harper's Magazine, 129-132.

Documents upon Napoleon and Education. (n.d.). (2016). Retrieved June 10, 2016, from http://www.napoleonseries.org/research/government/legislation/c_education.html. 
Eikenberry, D. H. (1923). Permanence of high school learning. Journal of Educational Psychology, 1(4), 463481. https://doi.org/10.1037/h0073932

Fabiano, G. J. (1962). Unit approach in college teaching. Improving College and University Teaching, 10(2), 8790. https://doi.org/10.1080/00193089.1962.10532157

Harnett, P. (2009). Tarihin yerel, bölgesel, ulusal, Avrupa ve küresel boyutlarını dengeli bir şekilde ilişkilendirmek. In S. Aktekin, P. Harnett, M. Öztürk \& D. Smart (Eds.), Çok Kültürlü bir Avrupa için Tarih ve Sosyal Bilgiler Ĕgitimi (pp. 147-160). Ankara: Harf.

Harris, R., \& Burn, K. (2016). English history teachers' views on what substantive content young people should be taught. Journal of Curriculum Studies, 48(4), 518-546. https://doi.org/10.1080/00220272.2015.1122091

Hewson, C. (2014). Qualitative approaches in internet-mediated research: Opportunities, issues, possibilities. In P. Leavy (Ed.), The Oxford Handbook of Qualitative Research Methods (pp. 423-452). New York: Oxford University.

Hopkins, K., Peters, T., \& Schubeck, K. (1995). Teaching children. Phi Delta Kappan, 76(8), 633-636.

Joinson, A., \& Paine, C. B. (2007). Self-disclosure, privacy and the Internet. In A. Joinson, K. McKenna, U. Reips \& T. Postmes (Eds.), Oxford Handbook of Internet Psychology. Oxford: Oxford University.

Kaplan, A. M., \& Haenlein, M. (2010). Users of the world, unite! The challenges and opportunities of social media. Business Horizons, 53(1), 59-68. https://doi.org/10.1016/j.bushor.2009.09.003

Koren, S., \& Najbar-Agičić, M. (2007). European experience and the history curriculum in compulsory education. Metodika, 15, 344-372.

MEB. (2018a). Ortä̈ğretim tarih dersi (9, 10 ve 11. Siniflar) ögretim programı. Retrieved October 20, 2019, from http://mufredat.meb.gov.tr/Programlar.aspx

MEB. (2018b). Sosyal bililer dersi ögretim programı (ilkokul ve ortaokul 4, 5, 6 ve 7. sinıflar). Retrieved October 20, 2019, from http://mufredat.meb.gov.tr/Programlar.aspx

MEB. (2018c). T.C. inkılap tarihi ve Atatürkçülük dersi öğretim programı (ortaokul 8. sınıf). Retrieved October 20, 2019, from http://mufredat.meb.gov.tr/Programlar.aspx

Oliveria, M., Bitencourt, C., Teixeria, E., \& Santos, A. C. (2013). Thematic content analysis: Is there a difference between support provided by the MAXODA and NVivo softpare packages. In A. Mesquita \& I. Ramos (Eds.), ECRM2013 Proceedings of the $12^{\text {th }}$ European Conference on Research Methodology for Business and Management Studies. Retrieved October 18, 2019, from http://www.proceedings.com/18569.html

Pala, F., \& Şimşek, A. (2016). Sosyal bilgiler derslerinde tarihlerin (dates) öğretimi. Turkish History Education Journal, 5(1), 136-156.

Phillips, R. (1999). History teaching, nationhood and politics in England and Wales in the late twentieth century: A historical comparison. History of Education, 28(3), 351-363, https://doi.org/10.1080/004676099284672

Powell, D. A., Jacob, C. J., \& Chapman, B. J. (2012). Using blogs and new media in academic practice: Potential roles in research, teaching, learning, and extension. Innovative Higher Education, 37(4), 271-282. https://doi.org/10.1007/s10755-011-9207-7

Safran, M., \& Şimşek, A. (2006). İlköğretim öğrencilerinde tarihsel zaman kavramının gelişimi. İlköğretim Online, 5(2), 87-109.

Şimşek, A. (2007). İlköğretim 5. sınıf öğrencilerinin kronolojik algılarının geliştirilmesine yönelik yarı deneysel bir çalışma. Kuram ve Uygulamada Eğitim Bilimleri, 7(1), 589-615.

Şimşek, A. (2017). 2017 taslak tarih 9-10-11, Türk kültür ve medeniyet tarihi öğretim programlarının eleştirisi. Turkish History Education Journal, 6(1), 140-162.

Şimşek, A., \& Bal, S., M. (2010). Tarih şeridi aracılı̆̆ıyla öğretmen adaylarının tarihsel zaman algılarının incelenmesi. Sosyal Bilgiler Eğitimi Araştırmaları Dergisi, 1(1), 124-151.

Smart, D., \& Harnett, P. (2009). İngiltere'de tarih öğretim programı: Tartışmalı anlatılar. In S. Aktekin, P. Harnett, M. Öztürk \& D. Smart (Eds.), Çok Kültürlü bir Avrupa için Tarih ve Sosyal Bilgiler Eğitimi (pp. 103-120). Ankara: Harf.

Smith, R. H. (1930). The unit plan in operation. The Journal of Education, 112, 548-549. 
https://doi.org/10.1177/002205743011202207

Stow, W., \& Haydn, T. (2000). Issues in the teaching of chronology. In J. Arthur \& R. Phillips (Eds.), Issues in History Teaching (pp. 83-97). London: Routledge.

Stradling, R. (1997). Teaching the history of Europe in the 20th century: Approaches and problems. Council for Cultural Cooperation Project on "Learning and Teaching About the History of Europe in the 20th Century in Secondary Schools". Retrieved October 21, 2019, from https://rm.coe.int/CoERMPublicCommonSearchServices/DisplayDCTMContent?documentId=0900001680 49422a

Tanaka, S. (2019). History without chronology. Massachusetts: Lever. https://doi.org/10.3998/mpub.11418981

Thacker, J. (2007). A study of a theme-based curriculum for secondary American history education. Unpublished doctoral dissertation. Texas A\&M Universitesi, Kigsville.

Turan, İ. (2018). Lise tarih öğretmenlerinin öğretim programı geliştirme süreci ve güncellenen öğretim programına dair görüssleri. V. Uluslararası Tarih Ë̆itimi Sempozyumu Tam Metin Bildiriler, 603-614. Retrieved October 9, 2019, from http://historyeducation.org/arsiv/

Wakeford, N., \& Cohen, K. (2008). Fieldnotes in public: Using blogas for research. In N. Fieldin, R. M. Lee \& G. Blank (Eds.), The Sage Handbook of Online Research Methods (pp. 307-326). London: Sage. https://doi.org/10.4135/9780857020055.n17

Waldman, A. (2009). The politics of history teaching in England and France during the 1980s. History Workshop Journal, 68(1), 199-221. https://doi.org/10.1093/hwj/dbp005

White, R. (1994). An alternative approach to teaching history. OAH Magazine of History, 8(2), 58-60. https://doi.org/10.1093/maghis/8.2.58

Wineburg, S. S. (1995). The psychology of learning and teaching history. In D. Berliner \& R. Calfee (Eds.), Handbook of Educational Psychology. New York: Macmillan.

Zevin, J. (2000). Social studies for the twenty-first century: Methods and materials for teaching in middle and secondary schools. Mahwah, NJ: Lawrence Erlbaum.

\section{Copyrights}

Copyright for this article is retained by the author, with first publication rights granted to the journal.

This is an open-access article distributed under the terms and conditions of the Creative Commons Attribution license (http://creativecommons.org/licenses/by/4.0/). 